\title{
New Era in Pakistan's Foreign Policy: Problems and Prospects
}

\author{
Fauzia Darabu \\ Ph. D Scholar \\ Department of Humanities and Social Sciences \\ Greenwich University - Karachi \\ fauziadarabu@gmail.com \\ $\&$ \\ Prof. Dr. Sayeda Daud \\ Dean, Faculty of Humanities \& Social Sciences, \\ Greenwich University - Karachi \\ Karachi-Pakistan \\ sayedadaud@gmail.com
}

\begin{abstract}
Pakistan has a long history of economic and political instability despite being an ally of the west. All national and external decisions were dependent on the interests of these powers. Pakistan never had the opportunity to establish either a strong democratic government or to pursue any independent, foreign relations since 1947specially during Soviet invasion of Afghanistan, in December, 1979. Despite of sacrificing lives of many of her citizens during the War on Terror after 9/11, instead of appreciation form the West especially the US, Pakistan was labeled as a terrorist and an extremist Muslim Country. Kept isolated from the International Community, Pakistan was left no choice but to look for a more regional ally with common interests. Joining hands with China, the most trusted friend and an economic giant, seemed the only option. In this way, Pakistan hoped to play a better international role by having relations with all players in the region. To find out the root causes of these problems, a Qualitative Research Method was applied for a descriptive, in-depth critical analysis by, reliable and authentic primary
\end{abstract}


and secondary sources. This research has made an attempt to clarify the risks and the stance of US as a stake holder; China-Pakistan relations, especially in the context of $C P E C$. The research has tried to highlight the importance of a state's self-reliance and freedom to have an independent foreign policy of a developing country like Pakistan.

Key words: Foreign Policy of Pakistan, CPEC, Pak-US Relations, PakChina Friendship, Aids and loans.

\section{Introduction}

The foreign policy of a country is the device with which countries not only safeguard their interests in the region where they are located, but also it helps a country to promote its soft image in the world. Unfortunately, it is the dilemma of the Third World Countries that they fail to understand the game play of the strong nations. Pakistan is the example of one such country that has faced great economic and political instability due to the influence of strong states. Besides, she is defending herself on various fronts at a time to put the country's economy going smoothly. For keeping the name out of defaulters' list Pakistan was compelled to take loans from Saudi Arabia, UAE and China in 2019. The dilemma to have an exit from the "Grey List" of Financial Action Task Force is also a great challenge for her. (Alden \& Aran, 2016)

The aggression shown by India in occupied Kashmir on $5^{\text {th }}$ August 2019, is severe enough to keep Pakistan busy, diverting her attention to take some major steps to keep the country right on the track of development. The country is fighting for her sovereignty, stability and integrity. In these circumstances, the smooth completion of CPEC has become a matter of "Do or Die" for Pakistan. (The New York Times, 2019)

China is supporting Pakistan since long, whether it was during the war with India, when Pakistan was facing economic sanctions after she conducted nuclear tests in May 1998, the floods, the earth quacks of 2005 or the issue 


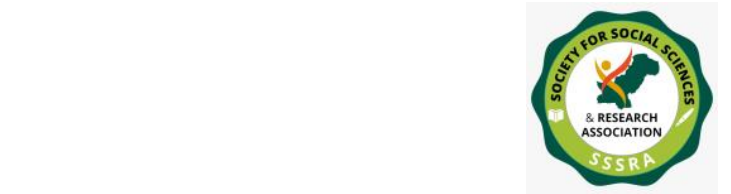

of Kashmir in Security Council in 2019, China has always acted like a protected shield for Pakistan.

As far as the US is concerned it is not a hidden secret as how the has US has behaved with Pakistan. The last decade has witnessed the "Do More Policy" for Pakistan, but a supportive act towards India, be it military aid, supporting Indian stance on Kashmir issue or making every attempt to make her the "Most Favorite Nation". It is quite amazing that though India never signed the treaties of SEATO and CENTO with the Americans, the US has always shown a soft corner for India as compared to Pakistan .( Burke \& Ziring, 1990)

In this scenario, Pakistan is taking the brunt of the west in general and of the US Government in particular by engaging more with China specially in launching including the project, China Pakistan Economic Corridor. This economic venture is being witnessed by the US as the closeness of an Islamic Country Pakistan, towards a communist country. The fact is that the US, is thinking that Pakistan, being her, "ally" has revisited her foreign policy and is getting closer to China and her friends. It has also been assumed that Pakistan along with China, Russia, Iran and other nearby states is going to form a separate "bloc" which in turn is a political strategy of China to curtail the US influence in this region. The question arises as why Pakistan cannot decide about her own foreign policy? Secondly, why should Pakistan justify her actions and why she has to have the US consent for having an economic venture with China which may give a boost to her tumbling economy? ( Sattar, 2010)

\section{Foreign Policy of Pakistan}

The geopolitical system of the world today revolves around the rules, laws and regulations of the Super powers' preference. In this scenario, a developing country like Pakistan could not be stopped from becoming an ally of a political hypocrite like USA. This superpower focused her attention towards Pakistan in 1950s when she invited our Prime Minister Liaquat Ali Khan and later supported Governor General Ghulam Mohammad and General Iskander Mirza, promising to lend her military and economic support. ( Burke and Ziring, 1990) 
At that time, it seemed quite a successful coalition against the odds Pakistan was facing economically and a threat to her sovereignty against India. However, the promises made by this super power vanished in the air when Pakistan needed help and the same became her foreign patron. This mismatched friendship resulted in threats to the territorial units of Pakistan and ended in the separation of East and West Pakistan. With the passage of time, US wielded greater influence on the political system of Pakistan. Consequently, there occurred severe problems both internally and externally. Pakistan failed in balancing its relations with all its neighbours without the directives of the Americans.( Sattar, 2010)

Therefore, if the UN has deemed that 'the integrity and stability for every single state would be binding' than why mighty nations have been continuously interfering in the domestic affairs of other countries? The actual fact is that some states have been intervening in the domestic policies of much weaker countries to fulfil their motives? As far as the case of United States is concerned, it has been observed that the super power has a different perception for different countries.

The extraordinary support to military regimes in Pakistan tells another side of the story. Facts show that the US government in 2009, approved $\$ 7.5$ billion of non-military aid to Pakistan through the Kerry- Lugar Bill. In February 2010, US President Barak Obama pushed forth approval of more funds to Pakistan to promote economic and political stability in a strategically vital, region. He also sought \$3.1billion aid in 2010 to defeat AL-Qaeda. (Kasuri, 2015)

It is being observed that "Developing countries are progressively losing their individual identities, rights and obligations vis-à-vis civil society, in the wake of external impositions. In other words, the disintegrative effects of globalization as well as the dissociative aspects of weak developing economies are increasingly undermining the twin pillars of non-intervention and state sovereignty".( Morgan, 2001).

The question is, as to how long the people of Pakistan will wait to break out of the charm of these strong political actors and when will they decide to unravel themes of depending on assistance of foreign powers to steer the 


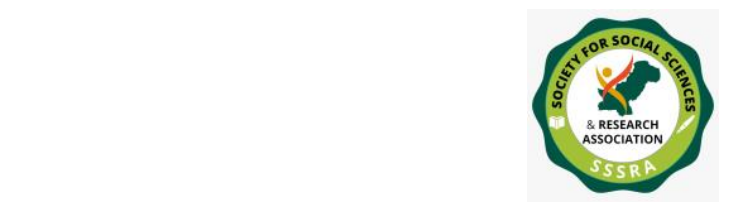

boat of the country's economy and has proved the last nail in the coffin for the stability of Pakistan. (Morgan, 2001)

The US government has been giving aids to Pakistan for education and health. Pakistan herself has been a front line ally of US since 50s. It has been observed that developed countries wish to support weaker states, using them for their own interests. As far as Pakistan is concerned, the world witnessed that a weak state has been held responsible for supporting Talibans and in turn compelling her to fight the war on terror on the behalf of the US.( Jalazai, 2004)

There is a long list of incidents where the USA has openly violated the rules of UNO which clearly state that: "Nothing contained in the present UN Charter shall authorize the United Nations to intervene in matters which are essentially within the domestic jurisdiction of any state".( Chapter I: Article 2(7). If this is the case than, why Americans have not been facing any kind of sanctions, embargos or a ban of any kind on their in countries, the list of which seems to be unending?

At present, with a new democratic government in power, the country is on the verge of being declared "Defaulter", the aggressive attitude of India on the eastern borders, the cross border conflict in unstable Afghanistan and an offended Iran on south west are challenges enough to make Pakistan realize to take some hard decisions in order to keep her sovereignty in- tact. The extended friendship with the emerging economic giant China and having peace in Afghanistan, and wishing to have good relations with Iran is the need of the hour for Pakistan. (Jalazai, 2004)

China has always extended cooperation to Pakistan to keep the country on the right track of development, and until now whether it is the case of taking a stance for Kashmir issue in the Security Council, or defending Pakistan's stance in order to keep her out of Black List of Financial Action Task Force. China has always extended her cooperation for political and non-political issues and has always been there for Pakistan, despite of the fact that both countries are good neighbours and Pakistan has not signed any treaty with China as she did in 50s like SETO or CENTO.( Ali, 2017) 
Unfortunately, the US has always given a deaf ear for issues related to Pakistan since 1947 and has supported India on every world forum. The aggressive behaviour of India, the non- ending series of violations by her on Pakistan's eastern borders, the non -ending curfew in Kashmir, the arrest of an Indian spy Kulbhushan Sudhir Jadhav have not been considered Indian insurgency by the US. If these incidents are merely accidents on Indians account for the US then why an economic project which would help Pakistan to fix her debts, to lift her economic sector, to bring prosperity in the country is being observed with a critical eye by the Americans?

This research would make an attempt to find the facts behind the questions as why closeness between Pakistan and China should be considered as a deviation in Pakistan's foreign Policy regardless of the fact that this economic project between two neighbouring countries is just to give boost to the economy of a developing state, Pakistan by a strong country, China. CPEC is a part of Chinese dream of One Belt Road. Pakistan's involvement in this project is to improve her economic disparity, not to support China to curtail the US influence in this region.

\section{Problem Statement}

Since the war on Terror, and the tragedy of 9/ 11, Pakistan is facing severe economic issues and political issues in the country. The new democratic Government of Mr. Imran Khan is having difficulty in keeping the country's economy running, for which the government had to take loan of nearly \$three billion from Saudi Arabia, \$ two billion by UAE and \$ two and a half billion by China (The Tribune, 2019) to get a Qualifying Certificate form International Monetary Fund on one hand and on the other the government was trying to keep the name of the country from the "Black List" of Financial Action Task Force. (Sherani \& Khan, October 2019).

The Relations of Pakistan with her neighbors are not improving with time. The discontinuation of the gas-pipe line issue, the attacks on both Iran and Pakistan near Baluchistan border has worsen the Pak-Iran relations and she has now close ties with India, as she has invested a large amount in the Chabahar Port. There is no sign of betterment in the peace talks between Afghan Taliban and US, and Pakistan is taking the brunt of restlessness in Afghanistan. 
India has kept Pakistan busy on Line of Control since long, killing innocent citizens. The latest Indian decision of revoking article $35-\mathrm{A}$ and 370 on $5^{\text {th }}$ August 2019, in which she has abolished the Independent status of the State of Jammu and Kashmir, has fanned the fire between the two countries and the relations between the two now a days are at its lowest level. (Aljazeera, 2019, August 9)

The Trump Government has offered to become the mediator between India and Pakistan over the Kashmir issue on one hand but at the same time Mr. Trump has shown his inclination towards India by attending a gathering in the US, August 2019, at Huston.

The speech at the UNO by the Pakistan prime Minister has raised concerns in the western countries especially in the US and current close relations with China, her support on Kashmir issue in the Security Council in 2019, and her economic project CPEC has made the US assumed that there might be a shift in the foreign policy of Pakistan.

Pakistan is in under heavy debts and is struggling hard to stabilize her both internal and external problems. In this scenario, CPEC is considered as the life line for the economy of Pakistan.

This paper has attempted to discuss the concerns of the West especially the US for a change in the foreign policy of Pakistan and it has shed some light on the fact as why a developing country and an ally of the US was compelled to revisit her foreign policy, if it is there.

\section{The American Foreign Policy and Pakistan}

It is observed that the Americans like democracy only on paper but the real fear of democracy in other parts of the world is cemented in the US psyche. It would mean a severe lapse of control where they are involved. It clearly means that the American interest in this region was purely based upon the perception of funding the countries where they foresee their own interest. Pakistan has been an ally of USA since the Cold War when the Americans wanted countries of this part of the World to counteract against the Russians till the 1980s. (Haqqani, 2013) 


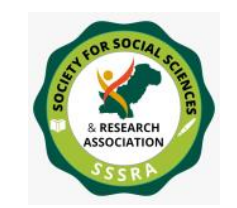

To safeguard its own interest, the Americans have supported military in particular and weak democratic governments in general in many countries including Pakistan, so that with their support, the ruling parties would remain obliged to the Americans. (Markey, 2013)

It has pointed out that by 1985; Pakistan was the fourth largest recipient of US bilateral military assistance, after Israel, Egypt and Turkey. It is also evident that Pakistan was the second highest recipient of US $\$ 4.02$ billion of military and economic aid in 1987 after Israel, and this was the time when General Zia-ul-Haq was in the power and even in the Musharraf rule though it was not a democratic set up.

The problem is that since 1951, Pakistan has been unfortunate to rule the state without taking any dictation from others. Secondly since her inception, due to military threat from India, she has shown showed so much dependency on US -Aid that it is being assumed in Pakistan, that someone else is ruling Pakistan indirectly. (Kasuri, 2015) .Pakistan has to reshape its foreign policy and should overcome the glaring issues within the country where the stability of the state should top the list. As far as grants and aids are concerned, there are still some countries that are ready to support Pakistan with soft loan facility provided the government ensures that the grant or loan would be utilized for the right purpose.

Foreign policy is usually the collection of external relations carried out by a state in international relations, and consists of trade and humanitarian interactions, besides military actions. It involves a number of steps where the domestic politics plays an important part. Unfortunately in Pakistan the domestic policies have been over shadowed in the name of loans, aids and grants either by a super power or by rich Arab States. (Alden, \& Aran, 2016)

The Nations who carve out their domestic policy on the basis of achieving goals of their foreign policy always pay off in the favor of the country though it may take years to accomplish this kind of success. Domestic policy is usually drawn by the head of a state which has to be rational enough to understand the political environment of his country and the matters which would cause internal conflict among the local people because 
of various factors which religion, sect, language, caste or creed. (Katzenstein, 1976)

After the incident of 9/11, Pakistan was declared a country, supporting the Islamic Extremists. Though it is a game play of all those countries who wanted to destabilize Pakistan, but the two military regimes in the country followed the foreign dictation and made the domestic policies which not only suited the foreign powers but also strengthened their rule also. In such situation, the country has no choice but to frame its domestic policy in accordance with its own survival needs. (Kasuri, 2015)

\section{China-Pakistan Economic Corridor and Foreign Policy of Pakistan}

CPEC is a significant component of OBR and a bilateral project between two good neighbors. This project would not only benefit the major shareholders but would connect the leading land and sea routes of the region. CPEC would also enhance its connectivity from Turkey to the Central Asia and even India, provided she wishes to become a part of this project. (Ali, 2017)

This Project would reduce the economic dependency of the countries of the region, revitalizing their economic activities, prosperity and security problems of the region. That is why currently nearly sixty countries have shown interest in this economic venture, including Russia. CPEC due to its geopolitical location and strategic arrangement would play the role of a "Game Changer" in the whole Indo- Pacific Region. It has been said that if CPEC, a unique segment of OBOR efficaciously gets complete, then the region of South Asia would become the "Economic Hub" both for the East and the West, relieving the developing countries from the clutches of the “AID SYNDROME" of the powerful countries.( Ali, 2017)

\section{CPEC \& Recompenses for Pakistan}

Energy act as "Jugular Vein" for any country (Adnan and Fatima, 2016) and without it any state would come to a standstill position. Pakistan is one such state where the people are still facing energy crisis and the productivity of the country has gone down drastically. 
With the completion of CPEC, the energy sector would get a big relief as it is assumed that around 10,400 Maga Watts would be added to the national grid system in its initial phase only, expected to get complete in 2018. ( Ali, 2017).

CPEC will also facilitate Pakistan to provide optimum benefit not only on local but at regional and intra-regional level. It would support the expansion in trade for Pakistan on the east, north and the west, provided if India also shows interest in One Belt Road project. It has been observed that CPEC may become a source of unrest among the people of Pakistan as some provinces have shown reservations against it.( Fair, 2017)

Thus, this research would make an attempt to find the factors which may be the sore points for the US as long as foreign policy of Pakistan is concerned. Secondly, this paper would also shed light as how powerful nations manipulate and influence the policies of weaker states when it comes to their domestic policies in general and foreign policy in particular. Thirdly the researcher also wish to find the real objectives of a super power behind her reservations against the cordial relations between China and Pakistan and why she considers this project the main reason for the change in the foreign policy of Pakistan.

\section{Objectives}

1) To observe the multitude problems faced by Pakistan due to inclined foreign policy since her inception.

2) To determine that there is a need to reshape the foreign policy of Pakistan in order to strengthen its economic and political stability.

\section{Research Questions}

Q1) Why the US considers Pakistan - China friendship as a deviation in her foreign policy?

Q2) Can Pakistan affords to show an inclination towards so called Chinese bloc? What implications Pakistan may face during the course of the completion of CPEC?

\section{Significance:}


Through this research, an effort is being made to draw the attention of the world to the fact that how a developing country like Pakistan has been manipulated, used and still is being dictated by the Americans and other powerful nations in the name of loans, grants and aids, since her inception. This research will point out that how the project CPEC is being considered as a step to support China to extend her influence in the South Asian region by the west in general and by the US in particular, although this economic venture would help Pakistan not only to get rid of her loans from different countries including IMF and how she needs it to put the country back on track on the road of development.

\section{Review of Literature}

\section{Meaning and Importance of Foreign Policy}

Khurshid, (1992) defines foreign policy as cultural, religious, economic , and moral aspect of the ideology of any country. On the other hand, Tarik (1992) argues about the meaning of foreign policy by expanding its meaning to five areas. First, the national interest should be the priority of any foreign policy, and then the different strategies should be considered to be applied according to the situations. Third, policy should be made flexible, fourth there should be cordial and congeal relations with all the countries especially the neighboring countries and last but not the least to utilize and materialize the global political environment in the country's favor.

Iram, Et al (2013) have outlined the factors which usually formulate the foreign policy of any nation. Among others, military capability of countries particularly of the neighboring countries has to be taken into consideration as it limits a country's strength.

While stressing upon foreign policy, Webber, \& Smith,(2014) are of the view that it is the capability of the politicians or decision makers to implement foreign policy. None of the policies would have worth, if the choices and the decisions are not being acted upon for a state.

Foreign Policy of any state revolves around its history, culture, institutions behavior of rulers of the state, given an indication that as how other states is 
going to behave. It also get affected by the international political system in which the states of the world live. (Alden, \& Aran, 2016).

\section{An Overview of Foreign Policy of Pakistan}

Foreign Policy of Pakistan has been the weakness of the politicians because of which the country's journey towards her neighbor witnessed ups and downs since 1947. The foreign policy thus can be divided into six different phases:

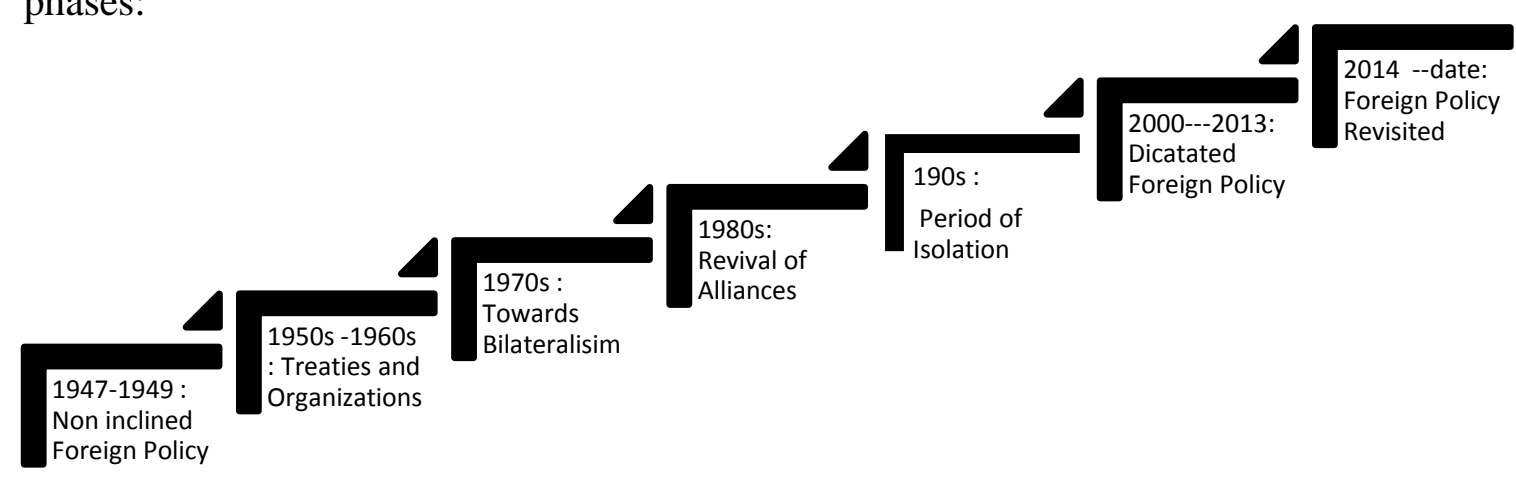
i) 1947
1949

Quaid-e-Azam, the founder of Pakistan clearly said that " Pakistan believe in the principles of honesty and fair play in national and international dealings and are prepared to make contribution to the promotion of peace and prosperity among all nations of the world. Our country will never be lacking in extending the material and moral support to the oppressed and suppressed people of the world and in upholding the principles of the United Nations Charter. So, an independent foreign policy will be followed."

ii) $1950 \mathrm{~s}$ 1960s

According to Amin, (2000) this era indicates the weakness of the political leadership of Pakistan. The treaties like Mutual Defense Assistance Agreement with America and South East Asia Treaty Organization in 1954 were signed not only to appease the US, but assuming that in this way Pakistan would have an upper hand over India. The Government of Pakistan also signed the Baghdad Pact on $23^{\text {rd }}$ September 1955, which annoyed the 


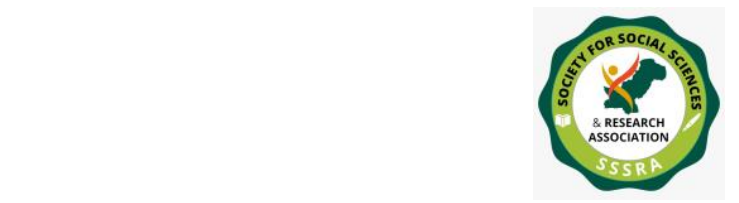

Pak. Journal of Int'L Affairs, Vol 4, Issue 1 (2021)

New Era in Pakistan's Foreign Policy...

Muslim World. This period of foreign policy of Pakistan, put a big question mark on the diplomatic credibility of the country and was tagged as a "Dictated Foreign Policy."

The author is of the view that Pakistan's foreign policy tried to get on its feet when Husain Shaheed Suharwardy took the office and tried to mend its fault by supporting Egypt over the issue of Suez Canal. At that time USA granted \$29.5 million to Pakistan, but the then President Ayub and the Prime Minister both, denigrate this act of the Americans.

Both Burke and Ziring (1990) are of the opinion that the Pakistan Government, after realizing that height of imperilment of their foreign policy shifted its attention to a newly emerged communist nation China which was in need of support on its stance against India as it blamed the later for supporting the separatist group in Tibet at that time.

Sattar, (2006) observes that Pakistan's inclination towards China created restlessness in the Western Alliance and America granted extra aid to Pakistan. The then Pakistan Government coldly welcome this aid and took a bold step against the trio that is India, USA and the then USSR. The manipulation of the strong nations against Pakistan took its final turn during the war of 1965 when USA refused to give any assistance in the war to Pakistan with India. President Johnson clearly threatened President Ayubs' Government to stay away from China or be ready for the grave consequences. Pakistan was left with no other option but to proceed with Tashkent Agreement in 1966 to settle the Kashmir Dispute.

Thus, the author is of the view that the Sino-Indian war opened up the eyes of the Pakistani Government and there came a shift in the Foreign Policy of Pakistan where they adopted a low profile attitude and decided to go for a policy of Bilateralism.

Kasuri, (2015) while discussing the world scenario during this period is of the opinion that there was an overall change in worlds' politics and slowly and gradually Pakistan seemed to be heading towards the path from where they could regain their political stability as an independent nation. During this era, China showed her modesty by supporting Pakistan's stance over Kashmir issue, under the leadership of the then Chinese Premier Liu Shaochis. Thus, the author is of the view that Pakistan's foreign policy of 50s and 
60 s, created a grave impact across the country of which unfortunately the rulers remained unaware.

\section{iii) Foreign Policy in 70s and 80s}

According to Sattar, (2010) the Pakistan Government thought to follow a policy of bilateralism in 70s as an amendment of their mistakes done in the past. The author declares that unfortunately, the proxy wars between the two super powers made Pakistan one complete province in the war of 1971. The author further observes that Mr.Bhutto, after holding the office of the Prime Minister, toured the Soviet Union, China, Cuba and Iran bearing the annoyance of the US.

Amin, (2000), discusses the situation in the region when the then Soviet invaded Afghanistan. The author also declares that this invasion forced the US government to acknowledge the importance of Pakistan and the Zia military regime.

Burke and Ziring, (1990) has regarded the situation beneficial for Pakistan as the US gave both economic and military support to Pakistan to act against the Russians on one hand and to help the Afghan Mujahedeen to fight the war against the military intervention on the other.

The authors are of the view that the US aid of $\$ 400$ milion both in terms of economic and military aid was later on raised to $\$ 600$ million by the then the Regan Administration. Pakistan suffered a lot in this proxy war and the future events revealed as how grave the political situation became for the future governments of Pakistan after getting involved of this proxy war in Afghanistan.

\section{iv) Foreign Policy in 90s}

According to Farooq (2016), the period of 1990s can be defined as a period of "Isolation". The end of Russian hold on Afghanistan made the Bush Administration to forget Pakistan. Pakistan suffered a lot, both on economic and political front. The author is of the opinion that the changed attitude of the US made Pakistan to take a strong stance on her decision for Occupied Kashmir and the necessity to conduct nuclear tests in May1998, keeping the 
sovereignty of the state intact. The author further adds that this action of Pakistan made her faced various economic and military sanctions by the US.

\section{v) Foreign Policy in 2000---2013}

Mazhr \& Goraya,(2013) are of the opinion that aftermath of 9/11, compelled Pakistan to make a shift in her foreign policy and anticipated in the 'War on Terror'. The author is of the opinion that though Pakistan was forced to participate in this war but this gave Pakistan an opportunity to join the main stream of world politics, and coming out of the period of Isolation.

Kasuri, (2015) declares that after 9/11, the Government of Pakistan faced problem to maintain a balance in relations between the US, Afghans as there was immense pressure on Pakistan to withdraw her support for Afghans. The author further adds that in order to minimize the US pressure, Pakistan started "Zarb-e- Azb" in the North Waziristan area.

The author concludes that this operation by Pakistan Army succeeded in eliminating the hideouts of Talibans on one hand but on the other hand became the cause of death of thousands of military personnel and civilians of the country. The author is of the opinion during this era Pakistan was compelled to follow the US instructions.

Sattar, (2010) strongly supports his point of view about the US government of 'never fulfilling its promises when it comes to Pakistan.' $\mathrm{He}$ announced outwardly that the US interference in the internal affairs of Pakistan made the country suffered a lot.

The loss of the second province in 1971 brought immense detriment to the country. The aftermath of War on Terror created chaos in Pakistan. The author observes that as Pakistan has suffered a lot in the past due to her inclined foreign policy, therefore in the current political scenario where Pakistan has the great support of China, she can take risk to revisit her foreign policy keeping the engagements of great powers under consideration.

Markey (2013), propounds that the relations between Pakistan and America have been never been bilateral and during this period Pakistan seemed to 
adopt a 'Yes Sir' behavior towards the US, as Pakistan was instructed to eliminate the root cause behind terrorism on both her north-western borders but also on the eastern borders.

Rana, (2015), observes that during this period, the relations between Pakistan and Russia showed improvement. The author observes that currently the relations between the two countries are far better as compared to $80 \mathrm{~s}$. He also discloses that both Pakistan and Russia have agreed to work jointly on the eradication of Narcotics from the region as well as shown interest in China Pakistan Economic Corridor.

Ali, (2017) observes that relations between Pakistan and China transformed into 'All Weather good Friendship' during this era. Author also discusses that this era witnessed closeness in ties between Pakistan and china and on his state visit to China, President of Pakistan Mr Asif Ali Zardari and the Chinese Premier Xi Jinping discussed in length about having an economic project named China Pakistan Economic Corridor.

The author also presumes that the friendship between the two countries has aroused suspicion in the West in general and in the US in particular and it is being assumed that China is trying to make an attempt to curtail the US influence in the region.

\section{vi) Foreign Policy 2014} till date

Pakistan security matters became worse during 2014 and thousands of citizens were killed during the operation carried out by Pakistan Army.

The PPP Government tried to ease the tension and started to have talks with the Talibans through Maulana Sami-ul-Haq. (Dawn.com,2014)

Kasuri, (2015) observes that the relations between Pakistan and India headed towards betterment during the tenure of PML-N tenure. Indian Prime Minister made visits to Pakistan during Nawaz government between 2015 and 2016, which gave the impression that all is getting well for both Pakistan and India.

The author also points out that the relations between Pakistan and the US were quite fragile as there were several acts of terrorism across the country. The author also discusses that since2014, relations reached its lowest level 


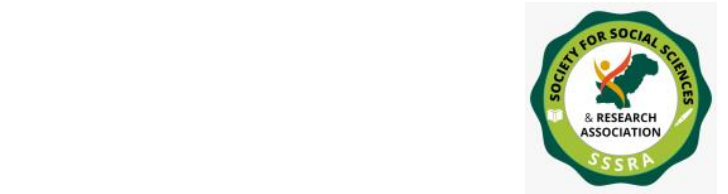

when the then advisor to Foreign Affairs Mr. Sartaj Aziz summoned the then Ambassador to Pakistan Mr. Richard Olson , conveying him the message of great concern about the report of Pentagon of involving Pakistan in the terrorist attacks in India and Afghanistan.

Mazhar \& Goraya, (2013) are of the opinion that the betterment in relations with India during the Nawaz rule was appreciated by the world. Both Pakistan and India attended the SAARC Summit Conference at Nepal, held in November, 2014. The authors observes that the relations between the two neighbors further showed improvement when the then Prime Minister Mr. Moodi visited Pakistan on a surprise visit in December, 2015.

Rafique, (2015) discusses about the relations between Pakistan and the US in length during 2015 and 2016.The US Government agreed to extend cooperation and to take appropriate steps to maintain peace in Afghanistan. The author is of the opinion that Pakistan for the first time took a firm stance not to agree with the US to declare India "The Most Favorite Nation" and wished that Super Power could adopt bilateralism in relations.

Farooqi, (2016) reports that absence of a permanent foreign minister in the country created problems for the government to take effective measures regarding relations of Pakistan with her neighbors and other countries. The author further adds that tension in relations between Pakistan and India aroused when a student Kashmiri leader Burhan Wani was martyred in 2016 by the law enforcing agencies in Occupied Jammu and Kashmir.According to the author, the relations reached to its lowest level when an Indian spy, Kal Bhushan Jadav was arrested from the Baluchistan province of Pakistan.

According to Tribune, (2017) the relations between Pakistan and the US went extremely worse during 2017. The US statement of calling India her new strategic partner compelled Pakistan to look upon to other countries for support. The pressure by the Trump Administration to Pakistan to do more for peace in Afghanistan was turned down by the Government of Pakistan asking the Trump Administration to ask the same from Afghanistan as Pakistan has done her part.

Griffith, in his report of 2017 declares that Pakistan for the first time strongly disagreed with the US, and asked her to realize and admit the way 
she has successfully carried out Zarb-e-eAzab eliminating the "Safe Heavens" from North and South Waziristan. The correspondent also reports that Pakistan has offered to be the mediator to commence the talks between the US and Afghan Talibans.

Jamal, (2018) reports that the new Government in Pakistan of Mr. Imran Khan has announced to continue her bilateral talks with all her neighbors including India. Mr. Khan invited India to come to the table to resolve the matters including that of Kashmir. Pointing to the US Pakistan relations, the correspondent is of the opinion that Pakistan wished to have peace in the region, as it is the only exit for all the countries of the region to attain economic stability. For the US the correspondent says, that the foreign Minister of Pakistan declares that Pakistan strongly believes in peace and wants to have equality in relations between the two countries.

Referring to the relations between China and Pakistan, the correspondent is of the opinion that close ties between China and Pakistan would lead to bring peace and prosperity in this region but the US is not happy with this closeness and assumes the possibility of formation of a bloc against her in the region.

\section{METHODOLOGY}

This paper is based on Descriptive Research with an in -depth analysis. Descriptive research ahs supported the researcher in discovering and understanding the possible factors which became the base of the shift in the foreign policy of Pakistan. For this paper, both Primary and Secondary sources have been utilized.

Primary Sources, the books have helped to gather the background history of the pattern of foreign policy of Pakistan. These books have been supportive in finding the events and facts which compelled to bring a change in the foreign policy of Pakistan especially after the tragedy of 9/11.

Secondary sources include some articles from reputed journals and newspapers and updated reports of some correspondents of famous newspapers and TV channels. This has supported the topic as they helped in strengthening the opinion of the researcher. 


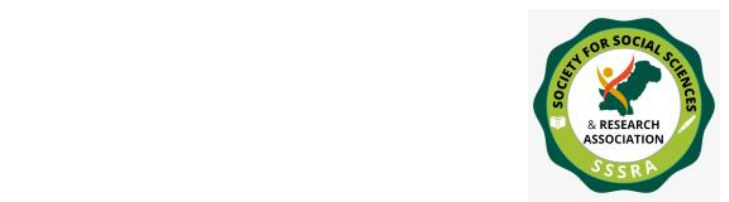

Grounded Theory has helped in organizing and gathering data in an organized way, which in turn supported the researcher to use the data for indepth analysis.

\section{DISCUSSION AND ANALYSIS}

This paper has propounded to discuss in depth the situation of a developing country Pakistan in the contemporary world of politics. The paper aims to discuss that when a country has a weak domestic policy with the leaders not being visionary, then that country faces as many problems like Pakistan has faced.

After partition, the unfair decisions by the Radcliffe Award regarding the princely states of Kashmir, Junagadh and Manavadr, and the extension in boundaries for India from Gurdaspur and Firozpur were the glaring issues for Pakistan to tackle with. Besides, the dispute over assets, canal water and mass migration of Muslims from India and their settlement were some of the major issues which kept the Government of Pakistan away to focus on to have a comprehensive and strategic foreign policy.

Pakistan has never been able to have a strong foreign policy as the governments after her founder was not visionary as was Quaid-e-Azam. Some unwise decisions by the then rulers during 1950s also played a great part in formulating weak foreign policy. The acceptance of US invitation and the rejection of the Soviet invitation after the inception of Pakistan created a problematic situation for the newly born state.

Foreign Policy of Pakistan showed slight deviation in 70s when Mr. Zulfiqar Ali Bhutto, the then Prime Minister of Pakistan visited the then Soviet Union, Cuba and Libya. It is worth mentioning here that this change in relations by Pakistan was not approved by the US. Interestingly, in late 70s, when the Soviets invaded Afghanistan the US extended her support and aid both military and financial to a dictator in Pakistan, General Zia-ul-Haq. This action proves that a super power can make a change in her policies when odds are against her.

The three short spells of democracy in Pakistan of both Benazir Bhutto and Nawaz Sharif created severe political instability in the country. It was this 


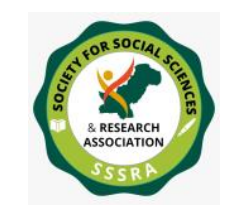

era when Pakistan tested her nuclear capabilities in 1998 and the country faced severe sanctions, both military and economic by the US.

It is difficult for the people of Pakistan to forget the aid which never came from the US in all the three wars of 1948, 1965 and 1971. Instead China, Iran was among the few who came for the support of Pakistan in the hour of need. China kept supporting Pakistan throughout in this difficult phase.

According to President Kennedy who in an address in 1961 declared that the US is a country which would take stand against injustice, inequality or aggression of any kind in the world. He emphasized that the Americans would always act like a shield for the weaker countries of the world. The question is that what would be the US reply to the intervention she did in Vietnam in 1965. Why did the US invaded Iraq in 2011, declaring her a state which has gone nuclear? How would the Americans justify her act against Libya in 2011, her role in Afghanistan since 2001? It is rather difficult to understand what the US tried to defend when she attacked Syria along with Saudi Arabia, Qatar and UAE in 2014?

In the contemporary world of politics, where the world is heading towards multipolarity, how the US maintains a world of unipolarity if she thinks she can by finding ways to intervene other countries?

In this current scenario, China the emerging economic giant is supporting a developing country Pakistan by engaging her in an economic venture named, China Pakistan Economic Corridor. This economic venture is a $\mathrm{n}$ important component of Chinese "One Belt Road" (OBR) and has become a source of annoyance and great worry for the US. The super power has assumed this project as a shift in the foreign policy of Pakistan. The US feels that this project is a Chinese's plan of curtailing the US influence in this region.

The fact is that Pakistan is under heavy debt and till now none of her allies has helped her in practical terms to get out of her debts. Lending grants and loans has made Pakistan to enter the "Grey List" of Financial Action Task force. At present Pakistan has been kept engage by India on her eastern borders and in Baluchistan. The north western borders, being porous has been kept Pakistan alert since 2000. Iran is not also happy with Pakistan and has close ties with India. 


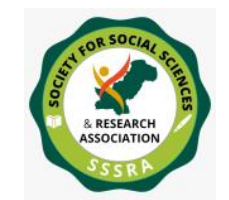

In this situation Pakistan cannot afford to have any other option but to look upon friends like China to get practical economic support from her in the form of CPEC. Pakistan wish to have good relations with Iran also and the Prime Minister Mr. Imran Khan have extended help to become a mediator between Saudi Arabia and Iran to resolve issues. Pakistan is also mediating in talks between the US and Afghan Talibans.

The Prime Minister of Pakistan Mr. Imran Khan during his speech at the $74^{\text {th }}$ Session of UNO has announced clearly that the world has ignored the aggression of some countries in areas like Syria, Palestine and Kashmir. He urged the United Nations to take appropriate measures to eliminate the factor of biasedness in the behavior of the world organization. He strongly condemned the Indian act in Kashmir and urged the US to stop India killing thousands of Kashmiris in Occupied Kashmir.

Recently, at the Annual Meeting of World Economic Forum at Davos, Switzerland, 22 January, 2020, The Prime Minister of Pakistan declared that learning from past mistakes, Pakistan would not get involved in a war on behalf of any other country. He very clearly said that Pakistan has suffered a lot during the War on Terror and the country is still not fully recovered from the economic loss.( Harris, 2020). He further added that Pakistan would keep on struggling through peace and good governance to uplift the weaker ones within the country. This is an indication as how Pakistan would mean to lead her affairs within and outside country.

The researcher has presented the case of Foreign policy of Pakistan keeping her past and present scenario into consideration. Pakistan has learnt a lot from her past mistakes. She is not fortunate to have a visionary leader like Quaid-e-Azam anymore. The present government has wished to continue good relations both with her neighbors and other countries and has promised to go to any length to eliminate corruption, injustice and biasedness from the society and to take Pakistan to the right track of progress and prosperity. For this achievement it is very important that Pakistan must have peace on her borders so that the government cab focus more in improving her domestic policies. 


\section{Conclusion}

No doubt, Pakistan has attained success in having peace in the NorthWestern borders and the tribal areas of the country have been merged in to the province of Khyber Pakhtunkhwa, in 2019 giving them a road map of prosperity and development. Current world scenario has changed rapidly due to COVID and other political events across the globe. Europe has been observing the worst economic scenario after World War II; the US is also struggling in resolving her internal matters due to change in the Government. Israel has stepping up in the Middle East, causing a threat for the Palestine and small Arab states. Turkey has grown in size and has become a voice for Pakistan at different forums. In this scenario, Pakistan has been struggling again to have an exit from the curtails of some strong Arab States including Saudi Arabia on the issue of acceptance of Israel and the project CPEC.

The issue is that Pakistan still is under heavy debt and has unable to find a solution to come out of this economic instability. Besides, she has to fulfill the demands of International Monetary Fund (IMF) and the FATAF. Therefore, she is unable to go ahead for a strong foreign policy which would support her in exploiting her geo-political location in the region. Foreign Policy of any country plays the role of a "GUARD" for a state but the guard has to be armed with weapons and for Pakistan, her poor economic situation has made her guard unarmed. This economic weakness has made Pakistan unable to have an independent foreign policy which in turn demands a strong economic position.

With new government in the US under Mr. Joe Biden, has yet to put forward the US foreign policy for South Asia, especially for Pakistan. China seems to be threating the US influence in the regions which once was the US domain. Now it is up to the ruling elites of Pakistan as how they play their cards in this tussel for more power between the US and China, as nor Pakistan can leave China, neither she can ignore the US.

Thus, the researcher is of the opinion that Pakistan, being a developing state should put all her effort in discovering ways to make her economy stable as only a strong economy can support her in following an independent foreign policy. 


\section{References}

Aftab, N. (2020, January 2). FATF (Financial Action Task Force) Working Group Meeting: Pakistani Delegation Reaches Beijing. The News International. https://www.thenews.com.pk/print/601448-fatfworking-group-meeting-pakistani-delegation-reaches-beijing

Akram, S. (2016). Pakistan Russia Relations: Future Trends. Islamabad: Institute of Strategic Studies. http://issi.org.pk/wpcontent/uploads/2016/03/Final-Issue-brief-Sarah-Akram-dated-24-32016.pdf.

Alden, C., \& Aran, A. (2016). Foreign Policy Analysis: New Approaches. Routledge.

Ali, G. (2017). China-Pakistan Relations: A Historical Analysis. Karachi: Oxford University Press.

Aljazeera (2019, August 9). Kashmir Special Status Explained: What are Articles 370 and 35A?

https://www.aljazeera.com/news/2019/8/5/kashmir-special-statusexplained-what-are-articles-370-and-35a

Amin, S. M. (2000). Pakistan Foreign Policy: A Reappraisal. 2nd ed. Karachi: Oxford University.

Bacevich, A. J. (2009). American Empire. Harvard University Press. London.

Blum, William. (2004). Killing Hope: US Military and CIA Interventions Since World War II Monroe, Louisiana: Common Courage Press.

Blum, William. (2013). Foreign America's Deadliest Export: DemocracyThe Truth About US Policy and Everything Else. London: Zed Books Ltd.

Bowden, M. (2012). The Finish: The Killing of Osama bin Laden. Atlantic Monthly Press. 
Burke, S. M., \& Ziring, L. (1990). Pakistan's Foreign Policy: An Historical Analysis. Karachi: Oxford University Press.

China Daily (2006). China-Pakistan Relations. http://www.chinadaily.com.cn/china/200611/14/content 732562.html.

Conteh-Morgan, E. (2001). International Intervention: Conflict, Economic Dislocation, and the hegemonic role of dominant actors. International Journal of Peace Studies, 6(2), 33-52.

Editorial Board New York Times. (2019, October 2). The U.N. Can't Ignore Kashmir Anymore: As India cracks down on a long-disputed region, two nuclear powers face off. The New York Times. https://www.nytimes.com/2019/10/02/opinion/editorials/kashmirindia-pakistan-un.html

Fair, C. (2017). Pakistan Can't Afford China's 'Friendship'. Foreign Policy. https://foreignpolicy.com/2017/07/03/pakistan-cant-afford-chinasfriendship.

Fair, C. Christine (2017, July 3). Pakistan Can't Afford China's 'Friendship' Foreign Policy. https://foreignpolicy.com/2017/07/03/pakistan-cantafford-chinas-friendship/

Farooq, T. (2016). US-Pakistan Relations: Pakistan's Strategic Choices in the 1990s. Routledge.

Farooqui, T. (2016). In Doldrums: Pakistan's Relations with its neighbors in 2016. The Express Tribune. https://tribune.com.pk/story/1278618/doldrums-pakistans-relationsneighbours-2016/

Grare, F. (2014). India-Pakistan Relations: Does Modi Matter?. The Washington Quarterly, 37(4), 101-114. 
Griffth, J. (2017, August 26). Who are the Key Players in Afghanistan? CNN https://edition.cnn.com/2017/08/26/asia/afghanistan-pakistanindia-china-russia-us/index.html.

Haqqani, H. (2013). Magnificent Delusions: Pakistan, The United States, and an Epic History of Misunderstandings. NewYork.TM Publications.

Haque, I. Ul. (2017, December 09). Pak-US Relations: A Glimmer of hope. The Express Tribune. https://tribune.com.pk/story/1579604/6-pak-usrelations-glimmer-hope/

Harris, B. (2020, January 22) 5 key quotes from Imran Khan at Davos. World Economic Forum. https://www.weforum.org/events/worldeconomic-forum-annual-meeting-2020.

Hey, J. A. K. (Ed.). (2003). Small States in World Politics: Explaining Foreign Policy Behavior. London: Lynne Rienner Publishers.

Hussain, T. (2017). Are India-Pakistan Relations Doomed?. The Stubborn Reralities in the Bilateral relationship show few signs of Changing anytime soon. The Diplomat. https://thediplomat.com/2017/04/areindia-pakistan-relations-doomed/

Jalālza'̄̄, M. K. (2004). The Foreign Policy of Pakistan: Kashmir, Afghanistan and Internal Security Threats, 1947-2004. Ariana Publications.

Jamal, S. (2018). Pakistan's New Foreign Policy targets developing ties with neighbours. Gulf News. https://gulfnews.com/world/asia/pakistan/pakistans-new-foreignpolicy-targets-developing-ties-with-neighbours-1.2268855

Jamal, S. (2018, August 20) Pakistan's new foreign policy targets developing ties with neighbors. Gulf News. https://gulfnews.com/world/asia/pakistan/pakistans-new-foreignpolicy-targets-developing-ties-with-neighbours-1.2268855. 
Jan, T. et. al. (1992). The Foreign Policy Debate: The Years Ahead. Islamabad: The Institute of Foreign Studies.

Kasuri, A. R. (2015). Neither Hawk nor Dove. Karachi: Oxford University Press.

Katzenstein, P. J. (1976). International Relations and Domestic Structures: Foreign Economic Policies of Advanced Industrial States. International Organization, 30(1), 1-45.

Keohane, R. O., Milner, H. V., Bates, R. H., \& Lange, P. (Eds.). (1996). Internationalization and Domestic Politics. England. Cambridge University Press.

Khalid, I. (2013). Pakistan Foreign Policy: Evolution, Development and Strategies. Lahore: Al-Abbas International.

Mahmood, T. (1994). Pressler Amendment and Pakistan's Security Concerns. Pakistan Horizon, 47(4), 97-107.

Mazhar, M. S., \& Goraya, N. S. (2013). Foreign Policy of Pakistan: Internal Challenges. Journal of Political Studies, 20(2), 91.

Notezai, A. M. (2017, July 09). Iran-Pakistan at the Crossroads? A Tradition of Cooperation is giving way to a much more complicated relationship. The Diplomate. https://thediplomat.com/2017/07/iranpakistan-at-the-crossroads/.

Notezai, A. M (2017) Purposes \& Principles of United Nations: Peace Dignity and Equality on a Healthy Planet. United Nation. https://www.un.org/en/sections/un-charter/chapter-i/index.html.

President Kennedy's Special Message to the Congress On Urgent National Needs, (1961, May 25). John F. Kennedy Presidential Library and Museum. https://www.jfklibrary.org/archives/other-resources/john-fkennedy-speeches/united-states-congress-special-message-19610525. 
Pyszczynski, T., Solomon, S., \& Greenberg, J. (2003). In the wake of 9/11: The Psychology of Terror. Washington DC, American Psychological Association.

Rafique, N. (2015). Pakistan-US Relations: Reset After 2011. Strategic Studies, 35(3). 24, 26, $28^{\text {th }}, 29$ and $30^{\text {th }}$ September, 2019 and $29^{\text {th }}$ October, 2019

Rana, Shahbaz (2019, February 2). China comes to Pakistan's rescue with $\$ 2.5 \mathrm{~b}$. loan. The Express Tribune. https://tribune.com.pk/story/1902080/1-china-comes-pakistans-rescue2-5b-loan.

Sattar, A. (2010). Pakistan's Foreign Policy, 1947-2009: A Concise History. Karachi: Oxford University Press.

Sattar, A. (2016). Pakistan's Foreign Policy 1947-2016. Karachi: Oxford University Press.

Sattar, A. (2017). Pakistan's Foreign Policy, 1947-2016: A Concise History. Oxford University Press.

Shahi, A. (1988). Pakistan's Security and Foreign Policy. Progressive Publishers.

Shaikh, F. (2012). Pakistan on the Brink: The Future of Pakistan, Afghanistan and the West. Penguin Books Ltd.

Singer, M., \& Wildavsky, A. B. (1996). The Real World Order: Zones of Peace, Zones of Turmoil. Chatham House Publisher.

Webber, M., \& Smith, M. (2014). The Implementation of Foreign Policy. In Foreign Policy In A Transformed World. Routledge. 105-130. 